\title{
Male Mortality from Conditions Sensitive to Primary Care Under The Perspective of The National Men's Health Policy
}

\author{
Cácia Régia de Paula ( $\nabla$ cregia@ufj.edu.br) \\ Federal University of Jataí \\ Bruno Bordin Pelazza \\ State University of the Center West \\ Flavio Henrique Alves de Lima \\ Universidade Federal de Goiás \\ Ludmila Grego Maia \\ Federal University of Jataí \\ Reila Campos Guimarães de Araújo \\ Federal University of Jataí \\ Yolanda Rufina Condorimay Tacsi \\ Federal University of Jataí \\ Lucila Pesuti Ferri \\ Federal University of Jataí \\ Gláucia Oliveira Abreu Batista Meireles \\ Centro Universitário de Anápolis \\ Pedro Lopes Ferreira \\ University of Coimbra \\ Ana Luiza Lima Sousa \\ Universidade Federal de Goiás \\ Marcos André Matos \\ Universidade Federal de Goiás \\ Maria Alves Barbosa \\ Universidade Federal de Goiás
}

\section{Research Article}

Keywords: Mortality, Primary Health Care, Human Health, Health Care Quality Indicators

Posted Date: January 24th, 2022

DOI: https://doi.org/10.21203/rs.3.rs-1277939/v1

License: @) (1) This work is licensed under a Creative Commons Attribution 4.0 International License. Read Full License 


\section{Abstract}

Background: To evaluate the trend of male mortality and its relationship with conditions sensitive to primary care (CSPCs), considering the coverage of the Family Health Strategy (FHS) and the implementation of the National Policy for Comprehensive Health Care of the Male (PNAISH).

Methods: Ecological study of the time series of male deaths in the age group of 20 to 59 years, according to CSPC from 2009 to 2018 with data extraction from the Mortality Information System. The relationship between death rate due to CSPCs and FHS coverage was quantified by Spearman's correlation. The trend in the number of deaths was adjusted by univariate quasi-Poisson regression models. Mortality trends were considered stationary ( $p>0.05)$, declining $(p<0.05$ and negative regression coefficient), or ascending $(p<0.05$ and positive regression coefficient). Values of $p<0.05$ were considered statistically significant.

Results: CSPCs were responsible for 1,092,070 (19.2\%) deaths in the 127 municipalities under study, a with year-on-year variation of $-4.89 \%$ to $3.06 \%$ and showed no significant relationship with mean FHS coverage $(r<0.09 ; p<0.160)$. PNAISH was implemented in $100 \%$ of the municipalities, and the FHS coverage showed a significant upward trend [95\% Cl; 1.03-1.09], with an annual average of $6 \%$. The trend of deaths in the study groups due to CSPCs was generally stable $(\operatorname{Exp}(\beta)=1.01 ; p>0.593)$. Notably, deaths in specific groups increased over time: bacterial pneumonia, asthma, hypertension, epilepsy, kidney and urinary tract infections, and skin and subcutaneous tissue infections. The heart failure group showed a decreasing mortality rate $($ Exp $(\beta)=$ $0.92 ; \mathrm{p}=0.008)$.

Conclusions: The expansion of FHS coverage and the fact that PNAISH was implemented in all municipalities in the state of Goiás did not influence the rate of deaths due to CSPCs in general. The analysis of death trends due to CSPCs in general indicates stability in the investigated period. The present study, the first of its kind in country, allows an evaluation of actions related to PNAISH, confirming the need for urgent investments. It can serve as feedback to researchers and policy-makers on interventions in humans.

\section{Background}

Women have a higher life expectancy than men worldwide. Scholars and health managers are concerned with the health of the male population [1]. Mortality rates are directly related to toxic masculinity, in which men, anchored in a socioculturally constructed and feedback-based sexist stance, find themselves invulnerable to illness and therefore do not avail themselves of health services [2,3].

Several countries have discussed specific policies for men, although only Brazil, Australia, the United Kingdom, and Ireland have implemented state policies [4-10]. In Brazil, the National Policy for Integral Attention to Male Health (PNAISH) was established in 2009, and in 2015 the state of Goiás officially implemented the state policy through ordinance. Both are firmly established within the Unified Health System (Sistema Único de Saúde - SUS) and recognize the care of the male population aged 20 to 59 years as an important and pressing public health problem [4, 11]. In addition, both are committed to primary health care $(\mathrm{PHC})$ through the Family Health Strategy (FHS) as the care provider and are responsible for the first contact of men with health services, thus requiring the target care strategies of all health services [4, 11-13]. National and international evidence shows that PHC has the potential to respond to 75 to $85 \%$ of the health needs of a community, especially when considering the characteristics and diversity of the treated population [14, 15].

Given the magnitude of the effort, several indicators were developed to evaluate PHC, and the Ambulatory Care Sensitive Conditions created by the United States of America were the precursor. In our country, analyses of the conditions sensitive to primary care (CSPCs) have proven useful by government agencies and have been the subject of numerous studies [16-18]. CSPCs are defined as diseases that can be controlled and reduced by means of accessible and effective PHC, which involves prevention and continuity of care. PHC use statistics indicate possible barriers to access to services (geographic, cultural, financial, or organizational) and help us monitor the effectiveness and performance of health services [18, 19].

There is robust evidence that male mortality rates are high and on the rise; that men have difficulties in accessing health services, often created by themselves, as they present only when a problem becomes urgent or emergent; and that the morbidity and mortality rates due to CSPCs are useful to evaluate the resolvability, quality, and accessibility of PHC, though we do not have any study specifically focussed on the male population. [17, 18, 20, 21]. We believe that exploring the information associated with the mortality of men aged 20 to 59 years by causes that are preventable and specific to the male population can make important advances in public health, both nationally and internationally, as it will help in the development and effectiveness of public policies that strengthen health care from the $\mathrm{PHC}$ level to the tertiary/quaternary.

In this context, we aimed to evaluate the trend or male mortality and its relationship with sensitive conditions to primary care, considering the coverage of the FHS and the implementation of PNAISH in the municipalities of the state of Goiás, a state in Central-West Brazil. The present study fills an important knowledge gap because it is the first study designed to evaluate PNAISH to support the planning of actions aimed at organizing and strengthening the men's health care system

\section{Methods}

This was an analytical ecological study of the time series of male deaths in the age group of 20 and 59 years, according to CSPC group, in the municipalities of a state in Central-West Brazil, from 2009 to 2018. This period was chosen due to the implementation of PNAISH in Brazil [4]. The data were extracted in June and July 2020 from the Mortality Information System of the Department of Information Technology of the Unified Health System (Sistema Único de Saúde - DATASUS). The state of Goiás is located in the central region of Brazil with a size of 340,203.329 km² and an estimated population of $7,113,540$ in 2020 , making it the 12th most populous state in the country, and it has 246 municipalities [22, 23].

Page 2/14 
The variables of interest were male sex in the age group of 20 to 59 years (age of coverage by PNAISH), municipality of residence, implementation of PNAISH in the municipality (yes/no), resident population of the municipality, death due to CSPC, year of death, and FHS coverage. The causes of CSPCs are described in Ordinance GM/MS no. 221 of April 17, 2008 [19]. The data files referring to deaths due to CSPCs per year were extracted through the electronic portal of the Department of Informatics of the SUS [24, 25].

In the Tabwin program, the following variables were selected: Row: Municipality of residence; Column: Age group; Increment: Frequency; Archives: DOGO 2009.dbc to DOGO 2018.dbc; Available selections: Sex; Age group (13); UF Resid; Year of Death; Municipality - GO; ICD10 4C Cap 1,

$2,3,4,6,7,8,9,10,11,12,13,14,15$.

It is noteworthy that all deaths of men aged 20 to 59 years registered in the Mortality Information System were eligible for the study, but only the medical diagnoses that were on the list of CSPCs were included in the analysis, to ensure the reliability of the data extraction process. The data extraction was repeated three times at different times and the results compared to each other, and we obtained the same results for different variables (sex, age group, and CSPC group).

Data on the population living in the municipalities of Goiás were obtained based on population estimates available on the DATASUS website [24]. Information related to the municipal implementation of PNAISH was extracted from official and public documents such as Annual Management Reports, Multiannual Plans, and Annual Health Plans of each municipality, year by year, in the period from 2009 to 2018, available on the Management Report Support System [26](SARGSUS) website and on the official website of the State Department of Health of Goiás [24, 27]. FHS is established as the originator of care and the gateway to the health system in municipalities, with a view to the reorganization of primary care and given the fact that PNAISH prioritizes primary care delivered under FHS [4, 11-13]. This municipality adopted policies whose official and public documents contained information that the municipality had specific coordination related to human health and/or performed actions equivalent to those described in the PNAISH within FHS. For the analysis of the FHS coverage situation of each municipality, we used annual data provided by the Department of Primary Care of the Ministry of Health, based on the situation recorded in December of each year. The information is available on the e-Gestor platform [28]. The findings were tabulated in Tabwin software version 4.15, a generic tab developed by DATASUS for the Windows operating environment, and subsequently transferred to R software version 3.6.1 for statistical analysis.

In the descriptive analysis of FHS coverage, which is a percentage variable and therefore numerical, measures of position, central tendency, and dispersion were used. To calculate the trend of FHS coverage, the logistic regression model was adjusted for the percentage of total coverage, by which we evaluated whether there was a trend of increasing FHS coverage over time. In the analysis of deaths and the municipalities' resident populations, the totals per year and other variables of interest were calculated, and the absolute and relative totals were calculated for ease of interpretation. To calculate the mortality rates due to CSPCs, events were the numerators and the exposed population was the denominator. The rates were adjusted to every 1,000 people. In addition, to evaluate the trend over time, the coefficient of variation was calculated year by year, which allowed us to evaluate how much the rates increased or decreased.

To verify the trend in the number of deaths due to CSPCs between 2009 and 2018, univariate quasi-Poisson regression models were adjusted for each CSPC group, and to evaluate the quality of the fit of this quasi-Poisson regression, we used Nagelkerke's pseudo- ${ }^{2}$. Mortality trends were considered stationary $(p>0.05)$, declining ( $p<0.05$ and negative regression coefficient), or ascending $(p<0.05$ and positive regression coefficient). Values of $p<0.05$ were considered statistically significant. Spearman's correlation was used to assess the relationship between mortality from CSPCs and FHS coverage. The Spearman correlation coefficient ranges between -1 and 1 : the closer the coefficient is to -1 , the stronger the negative correlation, and the closer the coefficient is to 1 , the stronger the positive correlation. Values of $p<0.05$ were considered statistically significant.

Data related to coverage and deaths were used to analyse spatialization. An auxiliary file of the shape of the state of Goiás, containing the geographic coordinates of the municipalities, was used as the file for map design. The map presented in this study was of the choropleth type, which shows the variation in colour tone.

Because this was an analytical ecological study of time series conducted with secondary data obtained from a public and open access system, it did not require approval from the research ethics committee. This study is part of the first author's doctoral thesis at the Federal University of Goiás, entitled "Analysis of male morbidity and mortality due to conditions sensitive to primary health care and its interface with human health".

\section{Results}

PNAISH had been implemented in all 246 municipalities in Goiás (100\%). However, in the last year of the series, only 179 (88.6\%) of the municipalities performed some action related to public health, although these actions in the male population showed an increase of $19.04 \%(2,018,036)$ in relation to the first year analysed. $(1,695,139)$.

As shown in Figure 1, a portion of the municipalities investigated did not have an FHS coverage greater than $80 \%$ of the population. Five (2.0\%) municipalities had less than $40 \%, 7$ (2.8\%) had between $40 \%$ and $60 \%$, and 27 (11.0\%) had between $60 \%$ and $80 \%$ FHS coverage. There was a significant upwards trend [95\% Cl; 1.03-1.09] of FHS coverage, with an average annual increase of only $6 \%$ [3\%; $9 \%$ ] in total coverage.

Over the years analysed, there were 363,776 deaths in private, public, and SUS-affiliated services from the state of Goiás. Of these, $59.7 \%$ were male $(217,085)$, and $40.2 \%$ were female $(146,403)$. Of the total deaths, $24.3 \%(88,324)$ were attributed to CSPCs. In total, $45,926(52 \%)$ and $42,372(47.98 \%)$ 
deaths occurred due to CSPCs among males and females, respectively, and $26(0.02 \%)$ had no recorded sex. By age group, $19.3 \%$ of deaths due to CSPCs $(8,877)$ occurred in men aged 20 to 59.

Figure 2 shows the spatial distribution of male deaths per CSPC group among the age groups of 20 to 59 years. In $32 \%$ of the municipalities investigated, there were between 5 and 15 deaths, and in $29.7 \%$ there were fewer than 5 deaths.

The absolute rate (per 1,000$)$ of mortality due to CSPCs ( $=8,877$; rate $=0.477$ ) showed year-on-year variation of $-4.89 \%$ to $3.06 \%$. The seven groups with the highest mortality rates were diabetes mellitus (DM) $(2,026 ; 0.109)$, cerebrovascular diseases $(1,621 ; 0.087)$, systemic arterial hypertension (SAH) $(1,169$; 0.063), heart failure (HF) $(1.014 ; 0.054)$, lung diseases (876; 0.047), gastrointestinal ulcers $(482 ; 0.026)$, and epilepsy (466; 0.025). In contrast, there were 101 patients (0.005) who died due to nutritional deficiencies, and the group with the lowest mortality rate was the anaemia group ( 8 ; $<0.001)$. Of the 17 CSPC groups, the diseases preventable by immunization and sensitive conditions ranked eighth with 368 (0.020) deaths (Table 1 ).

Table 1. Mortality rate by CSPC group in males, aged 20-59 years, 2009-2018. Goiás, Brazil, 2021. 


\begin{tabular}{|c|c|c|c|c|c|c|c|c|c|c|c|c|}
\hline $\begin{array}{l}\text { Group } \\
\text { CSPCs/Year }\end{array}$ & & 2009 & 2010 & 2011 & 2012 & 2013 & 2014 & 2015 & 2016 & 2017 & 2018 & Total \\
\hline \multirow{3}{*}{$\begin{array}{l}\text { 1. Diseases } \\
\text { preventable by } \\
\text { immunization } \\
\text { and sensitive } \\
\text { conditions }\end{array}$} & Deaths & 33 & 30 & 34 & 40 & 31 & 38 & 42 & 37 & 41 & 42 & 368 \\
\hline & $\begin{array}{l}\text { Rate }^{1} \text { (por } \\
1000)\end{array}$ & 0,019 & 0,017 & 0,019 & 0,022 & 0,017 & 0,020 & 0,022 & 0,019 & 0,021 & 0,021 & 0,020 \\
\hline & $\begin{array}{l}\text { Variation }{ }^{2} \\
(\%)\end{array}$ & -- & $-11,01 \%$ & $10,78 \%$ & $15,17 \%$ & $-24,04 \%$ & $20,24 \%$ & $8,49 \%$ & $-13,47 \%$ & $8,93 \%$ & $0,83 \%$ & -- \\
\hline $\begin{array}{l}2 . \\
\text { Gastroenteritis }\end{array}$ & Deaths & 7 & 8 & 19 & 9 & 13 & 9 & 10 & 11 & 6 & 2 & 94 \\
\hline infections & $\begin{array}{l}\text { Rate }^{1} \text { (por } \\
1000)\end{array}$ & 0,004 & 0,005 & 0,011 & 0,005 & 0,007 & 0,005 & 0,005 & 0,006 & 0,003 & 0,001 & 0,005 \\
\hline $\begin{array}{l}\text { and } \\
\text { complications }\end{array}$ & $\begin{array}{l}\text { Variation }{ }^{2} \\
(\%)\end{array}$ & -- & $11,87 \%$ & $132,15 \%$ & $-53,63 \%$ & $41,57 \%$ & $-32,09 \%$ & $9,06 \%$ & $8,05 \%$ & $-46,38 \%$ & $-67,19 \%$ & -- \\
\hline \multirow[t]{3}{*}{ 3. Anaemia } & Deaths & 2 & 2 & 0 & 0 & 1 & 0 & 1 & 1 & 0 & 1 & 8 \\
\hline & $\begin{array}{l}\text { Rate }^{1} \text { (por } \\
1000)\end{array}$ & 0,001 & 0,001 & 0,000 & 0,000 & 0,001 & 0,000 & 0,001 & 0,001 & 0,000 & 0,000 & 0,000 \\
\hline & $\begin{array}{l}\text { Variation }{ }^{2} \\
(\%)\end{array}$ & -- & $-2,12 \%$ & -- & -- & -- & -- & -- & $-1,77 \%$ & -- & -- & -- \\
\hline \multirow{3}{*}{$\begin{array}{l}\text { 4. Nutritional } \\
\text { deficiencies }\end{array}$} & Deaths & 12 & 10 & 11 & 8 & 10 & 10 & 13 & 11 & 6 & 10 & 101 \\
\hline & $\begin{array}{l}\text { Rate }^{1} \text { (por } \\
1000)\end{array}$ & 0,007 & 0,006 & 0,006 & 0,004 & 0,005 & 0,005 & 0,007 & 0,006 & 0,003 & 0,005 & 0,005 \\
\hline & $\begin{array}{l}\text { Variation }{ }^{2} \\
(\%)\end{array}$ & -- & $-18,43 \%$ & $7,52 \%$ & $-28,81 \%$ & $22,51 \%$ & $-1,91 \%$ & $27,60 \%$ & $-16,88 \%$ & $-46,38 \%$ & $64,04 \%$ & -- \\
\hline 5. Ear, & Deaths & 1 & 0 & 2 & 1 & 0 & 0 & 0 & 3 & 4 & 2 & 13 \\
\hline \multirow{2}{*}{$\begin{array}{l}\text { nose, and } \\
\text { throat } \\
\text { infections }\end{array}$} & $\begin{array}{l}\text { Rate }^{1} \text { (por } \\
1000 \text { ) }\end{array}$ & 0,001 & 0,000 & 0,001 & 0,001 & 0,000 & 0,000 & 0,000 & 0,002 & 0,002 & 0,001 & 0,001 \\
\hline & $\begin{array}{l}\text { Variation }{ }^{2} \\
(\%)\end{array}$ & -- & -- & -- & $-51,05 \%$ & -- & -- & -- & -- & $31,07 \%$ & $-50,79 \%$ & -- \\
\hline \multirow{3}{*}{$\begin{array}{l}\text { 6. Bacterial } \\
\text { pneumonia }\end{array}$} & Deaths & 10 & 11 & 28 & 25 & 16 & 25 & 21 & 32 & 32 & 39 & 239 \\
\hline & $\begin{array}{l}\text { Rate }^{1} \text { (por } \\
1000 \text { ) }\end{array}$ & 0,006 & 0,006 & 0,016 & 0,014 & 0,009 & 0,013 & 0,011 & 0,016 & 0,016 & 0,019 & 0,013 \\
\hline & $\begin{array}{l}\text { Variation }{ }^{2} \\
(\%)\end{array}$ & -- & $7,67 \%$ & $148,81 \%$ & $-12,60 \%$ & $-37,27 \%$ & $53,27 \%$ & $-17,55 \%$ & $49,68 \%$ & $-1,70 \%$ & $19,96 \%$ & -- \\
\hline \multirow[t]{3}{*}{ 7. Asthma } & Deaths & 6 & 6 & 9 & 7 & 4 & 8 & 5 & 7 & 12 & 16 & 80 \\
\hline & $\begin{array}{l}\text { Rate }^{1} \text { (por } \\
1000 \text { ) }\end{array}$ & 0,004 & 0,003 & 0,005 & 0,004 & 0,002 & 0,004 & 0,003 & 0,004 & 0,006 & 0,008 & 0,004 \\
\hline & $\begin{array}{l}\text { Variation }{ }^{2} \\
(\%)\end{array}$ & -- & $-2,12 \%$ & $46,62 \%$ & $-23,86 \%$ & $-44,00 \%$ & $96,19 \%$ & $-38,65 \%$ & $37,52 \%$ & $68,52 \%$ & $31,23 \%$ & -- \\
\hline \multirow{3}{*}{$\begin{array}{l}\text { 8. Pulmonary } \\
\text { diseases }\end{array}$} & Deaths & 90 & 72 & 77 & 77 & 89 & 95 & 88 & 98 & 98 & 92 & 876 \\
\hline & $\begin{array}{l}\text { Rate }^{1} \text { (per } \\
1000)\end{array}$ & 0,053 & 0,042 & 0,043 & 0,043 & 0,048 & 0,050 & 0,046 & 0,050 & 0,049 & 0,046 & 0,047 \\
\hline & $\begin{array}{l}\text { Variation }{ }^{2} \\
(\%)\end{array}$ & -- &,$- 69 \%$ & $4,53 \%$ & $-2,11 \%$ & $13,28 \%$ & $4,71 \%$ & $-9,08 \%$ & $9,39 \%$ & $-1,70 \%$ & $-7,60 \%$ & -- \\
\hline \multirow[t]{3}{*}{ 9. Hypertension } & Deaths & 88 & 93 & 99 & 104 & 134 & 125 & 139 & 115 & 151 & 121 & 1169 \\
\hline & $\begin{array}{l}\text { Rate }^{1} \text { (per } \\
1000 \text { ) }\end{array}$ & 0,052 & 0,054 & 0,056 & 0,057 & 0,073 & 0,066 & 0,072 & 0,059 & 0,076 & 0,060 & 0,063 \\
\hline & $\begin{array}{l}\text { Variation }{ }^{2} \\
(\%)\end{array}$ & -- & $3,45 \%$ & $4,05 \%$ & $2,83 \%$ & $26,28 \%$ & $-8,50 \%$ & $9,15 \%$ & $-18,73 \%$ & $29,07 \%$ & $-21,13 \%$ & -- \\
\hline \multirow[t]{3}{*}{ 10. Angina } & Deaths & 3 & 5 & 1 & 1 & 3 & 2 & 2 & 1 & 1 & 2 & 21 \\
\hline & $\begin{array}{l}\text { Rate }^{1} \text { (per } \\
1000)\end{array}$ & 0,002 & 0,003 & 0,001 & 0,001 & 0,002 & 0,001 & 0,001 & 0,001 & 0,001 & 0,001 & 0,001 \\
\hline & $\begin{array}{l}\text { Variation }{ }^{2} \\
(\%)\end{array}$ & -- & $63,14 \%$ & $-80,45 \%$ & $-2,11 \%$ & $194,03 \%$ & $-34,60 \%$ & $-1,84 \%$ & $-50,89 \%$ & $-1,70 \%$ & $96,85 \%$ & -- \\
\hline
\end{tabular}




\begin{tabular}{|c|c|c|c|c|c|c|c|c|c|c|c|c|}
\hline $\begin{array}{l}\text { 11. Heart } \\
\text { failure }\end{array}$ & Deaths & 144 & 142 & 100 & 115 & 108 & 99 & 80 & 87 & 70 & 69 & 1014 \\
\hline & $\begin{array}{l}\text { Rate }^{1} \text { (per } \\
1000)\end{array}$ & 0,085 & 0,082 & 0,056 & 0,064 & 0,058 & 0,053 & 0,042 & 0,045 & 0,035 & 0,034 & 0,054 \\
\hline & $\begin{array}{l}\text { Variation }{ }^{2} \\
(\%)\end{array}$ & -- & $-3,47 \%$ & $-31,16 \%$ & $12,57 \%$ & $-7,96 \%$ & $-10,08 \%$ & $-20,68 \%$ & $6,82 \%$ & $-20,91 \%$ & $-2,98 \%$ & -- \\
\hline \multirow{3}{*}{$\begin{array}{l}12 . \\
\text { Cerebrovascular } \\
\text { diseases }\end{array}$} & Deaths & 175 & 163 & 175 & 164 & 168 & 159 & 176 & 159 & 143 & 139 & 1621 \\
\hline & $\begin{array}{l}\text { Rate }^{1} \text { (per } \\
1000)\end{array}$ & 0,103 & 0,094 & 0,099 & 0,091 & 0,091 & 0,084 & 0,092 & 0,081 & 0,072 & 0,069 & 0,087 \\
\hline & $\begin{array}{l}\text { Variation }{ }^{2} \\
(\%)\end{array}$ & -- & $-8,83 \%$ & $4,94 \%$ & $-8,26 \%$ & $0,40 \%$ & $-7,16 \%$ & $8,65 \%$ & $-11,26 \%$ & $-11,59 \%$ & $-4,33 \%$ & -- \\
\hline \multirow{3}{*}{$\begin{array}{l}\text { 13. Diabetes } \\
\text { mellitus }\end{array}$} & Deaths & 160 & 173 & 177 & 216 & 209 & 198 & 233 & 222 & 223 & 215 & 2026 \\
\hline & $\begin{array}{l}\text { Rate }^{1} \text { (per } \\
1000)\end{array}$ & 0,094 & 0,100 & 0,100 & 0,119 & 0,113 & 0,105 & 0,121 & 0,114 & 0,112 & 0,107 & 0,109 \\
\hline & $\begin{array}{l}\text { Variation }{ }^{2} \\
(\%)\end{array}$ & -- & $5,84 \%$ & $0,01 \%$ & $19,46 \%$ & $-5,17 \%$ & $-7,07 \%$ & $15,51 \%$ & $-6,41 \%$ & $-1,26 \%$ & $-5,11 \%$ & -- \\
\hline \multirow[t]{3}{*}{ 14. Epilepsy } & Deaths & 32 & 29 & 43 & 39 & 54 & 48 & 53 & 56 & 59 & 53 & 466 \\
\hline & $\begin{array}{l}\text { Rate }^{1} \text { (per } \\
1000)\end{array}$ & 0,019 & 0,017 & 0,024 & 0,022 & 0,029 & 0,025 & 0,028 & 0,029 & 0,030 & 0,026 & 0,025 \\
\hline & $\begin{array}{l}\text { Variation }{ }^{2} \\
(\%)\end{array}$ & -- & $-11,29 \%$ & $44,93 \%$ & $-11,22 \%$ & $35,70 \%$ & $-12,81 \%$ & $8,38 \%$ & $3,79 \%$ & $3,57 \%$ & $-11,58 \%$ & -- \\
\hline \multirow{3}{*}{$\begin{array}{l}\text { 15. Kidney and } \\
\text { urinary tract } \\
\text { infection }\end{array}$} & Deaths & 13 & 13 & 17 & 17 & 20 & 12 & 20 & 19 & 24 & 33 & 188 \\
\hline & $\begin{array}{l}\text { Rate }^{1} \text { (per } \\
1000)\end{array}$ & 0,008 & 0,008 & 0,010 & 0,009 & 0,011 & 0,006 & 0,010 & 0,010 & 0,012 & 0,016 & 0,010 \\
\hline & $\begin{array}{l}\text { Variation } 2 \\
(\%)\end{array}$ & -- & $-2,12 \%$ & $27,82 \%$ & $-2,11 \%$ & $15,30 \%$ & $-41,14 \%$ & $63,59 \%$ & $-6,68 \%$ & $24,17 \%$ & $35,33 \%$ & -- \\
\hline \multirow{3}{*}{$\begin{array}{l}\text { 16. Skin and } \\
\text { subcutaneous } \\
\text { tissue infection }\end{array}$} & Deaths & 6 & 7 & 9 & 8 & 6 & 15 & 18 & 17 & 12 & 13 & 111 \\
\hline & $\begin{array}{l}\text { Rate }^{1} \text { (per } \\
1000)\end{array}$ & 0,004 & 0,004 & 0,005 & 0,004 & 0,003 & 0,008 & 0,009 & 0,009 & 0,006 & 0,006 & 0,006 \\
\hline & $\begin{array}{l}\text { Variation } 2 \\
(\%)\end{array}$ & -- & $14,20 \%$ & $25,67 \%$ & $-12,99 \%$ & $-26,49 \%$ & $145,23 \%$ & $17,79 \%$ & $-7,23 \%$ & $-30,61 \%$ & $6,63 \%$ & -- \\
\hline \multirow{3}{*}{$\begin{array}{l}17 . \\
\text { Gastrointestinal } \\
\text { ulcer }\end{array}$} & Deaths & 45 & 59 & 61 & 47 & 39 & 57 & 44 & 39 & 40 & 51 & 482 \\
\hline & $\begin{array}{l}\text { Rate }^{1} \text { (per } \\
1000)\end{array}$ & 0,027 & 0,034 & 0,034 & 0,026 & 0,021 & 0,030 & 0,023 & 0,020 & 0,020 & 0,025 & 0,026 \\
\hline & $\begin{array}{l}\text { Variation } 2 \\
\text { (\%) }\end{array}$ & -- & $28,34 \%$ & $1,06 \%$ & $-24,58 \%$ & $-18,67 \%$ & $43,37 \%$ & $-24,23 \%$ & $-12,93 \%$ & $0,82 \%$ & $25,49 \%$ & -- \\
\hline \multirow[t]{3}{*}{ Total } & Deaths & 827 & 823 & 862 & 878 & 905 & 900 & 945 & 915 & 922 & 900 & 8877 \\
\hline & $\begin{array}{l}\text { Rate }^{1} \text { (per } \\
1000)\end{array}$ & 0,488 & 0,475 & 0,487 & 0,485 & 0,490 & 0,478 & 0,493 & 0,469 & 0,464 & 0,446 & 0,477 \\
\hline & $\begin{array}{l}\text { Variation }{ }^{2} \\
(\%)\end{array}$ & -- & $-2,59 \%$ & $2,38 \%$ & $-0,29 \%$ & $1,02 \%$ & $-2,45 \%$ & $3,06 \%$ & $-4,89 \%$ & $-0,95 \%$ & $-3,92 \%$ & -- \\
\hline
\end{tabular}

The overall trend of deaths of men aged 20 to 59 years due to CSPCs was generally stable $(\operatorname{Exp}(\beta)=1.01 ; p>0.593)$. We also observed a trend of stability for the following groups of causes: diseases preventable by immunization and sensitive conditions $(p=0.380 ; \beta=1.03)$; infectious gastroenteritis and complications $(\operatorname{Exp}(\beta)=0.94 ; p=0.143)$; anaemia $(\operatorname{Exp}(\beta)=0.88 ; p=0.402)$; nutritional deficiencies $(\operatorname{Exp}(\beta)=0.98 ; p=0.605)$; infections of the ear, nose, and throat $(\operatorname{Exp}(\beta)=1.21 ; p=0.086)$; lung diseases $(\operatorname{Exp}(\beta)=1.02 ; p=0.405)$; angina $(\operatorname{Exp}(\beta)=0.90 ; p=0.187)$; cerebrovascular diseases $(\operatorname{Exp}(\beta)=0.98$; $p=0.421)$; diabetes $(\operatorname{Exp}(\beta)=1.03 ; p=0.158)$; and gastrointestinal ulcer $(\operatorname{Exp}(\beta)=0.98 ; p=0.434)($ Table 2$)$.

Table 2. Trend in the number of deaths by CSPC group, 2009-2018. Goiás, Brazil, 2020. 


\begin{tabular}{|c|c|c|c|c|c|}
\hline Group & $\operatorname{Exp}(\beta)$ & $95 \% \mathrm{Cl}$ & $\mathbf{R}^{\mathbf{2}}(\%)$ & $P$ value & Interpretation \\
\hline Deaths due to general CSPCs & 1.01 & {$[0.97 ; 1.06]$} & 0.4 & 0.593 & Stable \\
\hline Deaths due to diseases preventable by immunization and sensitive conditions & 1.03 & {$[0.96 ; 1.1]$} & 0.2 & 0.380 & Stable \\
\hline Deaths due to infectious gastroenteritis and complications & 0.94 & {$[0.86 ; 1.02]$} & 0.6 & 0.143 & Stable \\
\hline Deaths due to anaemia & 0.88 & {$[0.66 ; 1.18]$} & 1.0 & 0.402 & Stable \\
\hline Deaths due to nutritional deficiencies & 0.98 & {$[0.91 ; 1.05]$} & 0.0 & 0.605 & Stable \\
\hline Deaths due to ear, nose, and throat infections & 1.21 & {$[0.97 ; 1.51]$} & 2.7 & 0.086 & Stable \\
\hline Deaths due to bacterial pneumonia & 1.12 & {$[1.04 ; 1.2]$} & 2.2 & 0.002 & Increase \\
\hline Deaths due to asthma & 1.10 & {$[1 ; 1.2]$} & 1.0 & 0.050 & Increase \\
\hline Deaths due to pulmonary diseases & 1.02 & {$[0.97 ; 1.08]$} & 0.2 & 0.405 & Stable \\
\hline Deaths due to hypertension & 1.05 & {$[1.01 ; 1.09]$} & 1.0 & 0.019 & Increase \\
\hline Deaths due to angina & 0.90 & {$[0.77 ; 1.05]$} & 0.9 & 0.187 & Stable \\
\hline Deaths due to heart failure & 0.92 & {$[0.87 ; 0.98]$} & 2.6 & 0.008 & Reduction \\
\hline Deaths due to cerebrovascular diseases & 0.98 & {$[0.94 ; 1.03]$} & 0.2 & 0.421 & Stable \\
\hline Deaths due to diabetes mellitus & 1.03 & {$[0.99 ; 1.08]$} & 0.6 & 0.158 & Stable \\
\hline Deaths due to epilepsy & 1.07 & {$[1.02 ; 1.12]$} & 1.0 & 0.007 & Increase \\
\hline Deaths due to kidney and urinary tract infections & 1.09 & {$[1 ; 1.19]$} & 1.2 & 0.043 & Increase \\
\hline Deaths due to infection of the skin and subcutaneous tissue & 1.10 & {$[1.01 ; 1.21]$} & 1.3 & 0.031 & Increase \\
\hline Deaths due to gastrointestinal ulcer & 0.98 & {$[0.92 ; 1.03]$} & 0.1 & 0.434 & Stable \\
\hline
\end{tabular}

Source: DATASUS, Ministry of Health, 2020.

Highlights on the increase in deaths in the groups: bacterial pneumonia $(\operatorname{Exp}(\beta)=1.12 ; p=0.002)$, asthma $(\operatorname{Exp}(\beta)=1.10 ; p=0.050), \operatorname{SAH}(\operatorname{Exp}(\beta)=1.05$; $p=0.019)$, epilepsy $(\operatorname{Exp}(\beta)=1.07 ; p=0.007)$, kidney and urinary tract infection $(\operatorname{Exp}(\beta)=1.09 ; p=0.043)$, and infection of the skin and subcutaneous tissue $(\operatorname{Exp}(\beta)=1.10 ; p=0.031)$, an average increases of $12 \%$ [4\%; $20 \%] ; 10 \%[0 \% ; 20 \%], 5 \%[1 \% ; 9 \%], 7 \%[2 \% ; 12 \%], 9 \%[0 \% ; 19 \%]$ and $10 \%[1 \% ; 21 \%]$, respectively. Among the CSPC groups, only heart failure tended to have a reduced mortality rate over time $(\operatorname{Exp}(\beta)=0.92 ; p=0.008)$, with a decrease of $8 \%$ [2\%; $13 \%]$ on average each year (Table 2 ).

There was no relationship between the mortality rate due to CSPCs in the studied population and the average FHS coverage in the municipalities of Goiás $(p<0.160 ; r<0.09)$.

When stratified by group of causes, a significant and negative relationship ( $p<0.050 ; r<-0.28)$ was observed between the average FHS coverage and male mortality rates in the age group of 20 to 59 years in the following groups: diseases preventable by immunization and sensitive conditions; gastroenteritis infection and complications, nutritional deficiency; ear, nose, and throat infection; asthma; angina; epilepsy; kidney and urinary tract infection; infection of the skin and subcutaneous tissue; and gastrointestinal ulcer (Table 3).

Table 3. Spearman's correlation between male death by CSPC group and average FHS, 2009-2018. Goiás, Brazil, 2021. 


\begin{tabular}{|c|c|c|}
\hline \multirow[t]{2}{*}{ Rate/Group } & \multicolumn{2}{|c|}{ Average FHS coverage } \\
\hline & $\mathbf{r}^{1}$ & $P$ value \\
\hline Mortality rate due to general CSPCs & 0.09 & 0.160 \\
\hline Mortality rate due to diseases preventable by immunization and sensitive conditions & -0.25 & 0.000 \\
\hline Mortality rate due to infectious gastroenteritis and complications & -0.26 & 0.000 \\
\hline Mortality rate due to anaemia & -0.06 & 0.330 \\
\hline Mortality rate due to nutritional deficiencies & -0.19 & 0.003 \\
\hline Mortality rate due to ear, nose, and throat infections & -0.26 & 0.000 \\
\hline Mortality rate due to bacterial pneumonia & -0.10 & 0.129 \\
\hline Mortality rate due to asthma & -0.28 & 0.000 \\
\hline Mortality rate due to pulmonary diseases & 0.09 & 0.140 \\
\hline Mortality rate due to hypertension & -0.08 & 0.203 \\
\hline Angina mortality rate & -0.14 & 0.028 \\
\hline Mortality rate due to heart failure & -0.05 & 0.450 \\
\hline Mortality rate due to cerebrovascular diseases & -0.02 & 0.795 \\
\hline Mortality rate due to diabetes mellitus & 0.02 & 0.802 \\
\hline Mortality rate due to epilepsy & -0.13 & 0.038 \\
\hline Mortality rate due to kidney and urinary tract infections & -0.25 & 0.000 \\
\hline Mortality rate due to infection of the skin and subcutaneous tissue & -0.27 & 0.000 \\
\hline Mortality rate due to gastrointestinal ulcer & -0.17 & 0.007 \\
\hline
\end{tabular}

${ }^{1}$ Spearman's correlation coefficient. FHS: Family Health Strategy

Source: DATASUS, Ministry of Health, 2020; e-Gestor-Primary Care, 2020.

\section{Discussion}

This study allows for important reflections on the human health policy articulated in the FHS. Although all municipalities in the state of Goiás have implemented PNAISH, only $88.6 \%$ ran specific interventions in the last years of the study, confirming the need for investments in strategies that address the specificities of males.

The overall death rate in the male population was higher than that in the female population ( $59.7 \%$ vs. $40.2 \%)$, following national and international trends. In addition, $19.3 \%$ of deaths in men were due to CSPCs, i.e., preventable diseases that could be resolved in primary care [1, 29-31]. A study conducted in 2017 on the epidemiological profile of male mortality corroborates the results found in this study, indicating a higher proportion of male deaths from preventable causes in the age group of 50 to 59 years. These results may be partly explained by the fact that men prioritize work over prevention as young adults [2]

The present study showed a significant increase in the average FHS coverage in the municipalities, but still far from the recommended value. This growth did not occur uniformly: Some of the municipalities had coverage below $80 \%$, which is therefore reflected in deaths from CSPCs. Similarly, Andrade et al. [32] identified that the growth of FHS coverage in Brazilian municipalities occurs heterogeneously and associated this heterogeneity with financing mechanisms, the size of the population, and the continental size of the country.

The insufficiency of resources transferred by the federal government to municipalities compromises the quality of actions and of health care, forcing managers to focus their efforts on public policies of other demographics that have already shown success and have robust government criteria for evaluations, to the detriment of men's health policy, thus perpetuating the alienation of men from the health services, consequently raising their vulnerability to illness [33].

The spatial analysis indicated a geographical variation in the pattern of deaths in the municipalities under study and the spatial identification of risk areas for deaths due to CSPCs. This variation may be related to municipalities with low coverage of the Family Health Strategy and/or absence of quality actions related to human health, given that PNAISH is implemented in all municipalities in Goiás. It can also be inferred that this variation is related to the fact that the municipalities of Goiás are heterogeneous, differing from each other in a number of characteristics, such as size, population density (more than half of 
the municipalities have less than 10,000 inhabitants), level of socioeconomic development, and provision of health services [23]. Thus, it is urgent that we homogenize FHS coverage, as well as take more effective intersectoral actions to promote human health in all municipalities of the state of Goiás.

Our investigation showed that the groups of CSPCs that caused the most deaths were DM, cerebrovascular diseases, SAH, HF, and lung diseases. Several studies have reported results similar to these. This may suggest that men do not seek health care with a focus on disease prevention or that there are failures in primary care $[2,29,30,34]$. Several of these diseases have been the subject of exclusive public policies instituted by the Ministry of Health within the scope of FHS for more than three decades, such as the fight against noncommunicable chronic diseases, which addresses four main diseases (circulatory, cancers, chronic respiratory diseases, and DM), and the establishment of the National Programme of Pharmaceutical Assistance for SAH, DM, and Asthma, that have targeted other population segments, for example, the elderly [35-37].

Our findings point to a trend towards stability $(p>0.593 ; \beta=1.01)$ of deaths in general (when all groups were analysed together) due to CSPCs throughout the time studied. The only specific cause of death that showed a falling trend was heart failure. It is important to highlight the increasing tendency of deaths from bacterial pneumonia, asthma, hypertension, epilepsy, kidney and urinary tract infection, and skin and subcutaneous tissue infection and the tendency toward stability of deaths due to DM. The high mortality from these groups of CSPCs in men warns us of the need for a perennial evaluation of the programmes focussed on chronic conditions, which could observe if there is a possible relationship with the quality of the actions taken and the vulnerability of the population segment studied here, associated with the severity of the diseases of these cause groups or pre-existing comorbidities [9, 3840]. In addition, deaths related to diseases preventable by immunization and sensitive conditions ranked eighth among the 17 groups of CSPCs. Several scholars describe how the National Immunization Programme has expanded and impacted the morbidity and mortality profiles in Brazil, including the eradication of numerous diseases [41].

The data also reveal that there are weaknesses in primary care, which may be linked to the low adherence of men to health services, particularly for preventive actions $[13,21,33,42]$. Thus, it is necessary to sensitize the male population to self-care and expand the active search for men who have difficulties accessing health services. We believe that diseases preventable by immunization and sensitive conditions should be closely monitored, considering the current public-health impact of SARS-CoV-2 and the anti-vaccination movement.

It is noteworthy that the deaths occur at an economically active age in a target demographic covered by a specific policy, indicating an important socioeconomic and cultural impact on the state of Goiás, demonstrating the need to disseminate appropriate actions in an organized and planned manner according to the analysis of the health situation of these locations and the health care network. In this sense, the encouragement of intersectorality and transversality between existing public health policies could help minimize mortality rates among young adult men $[9,21,33,42]$.

The unprecedented nature of government policies for men in Brazil and other countries, by emphasizing the health of men, shows institutional barriers related to cultural issues and models of health care for men. According to several studies, the male population cites obstacles to the use of health services, the shame of exposing oneself, impatience in waiting for care, the lack of time, and the failure of the health care system to resolve their health needs. The fact that men still do not feel a part of the health services and do not see primary care as a gateway to health services are also factors to be considered. In addition, the centralized management of services, inadequate training of health professionals, the lack of appropriate training to provide quality health care, and the fragmentation of services provided to men have been cited $[9,10,13,21,33,43]$. Thus, it is imperative that the FHS formulate a men's health policy to ensure it is the men's first health-care contact and that it develop strategic actions to address the male audience by sensitizing them to the health service and self-care to make them realize the health service and make use of the actions offered [9, 10, 21, 42, 44]. Countries such as Ireland and Australia have bet on strategies to sensitize men regarding their well-being and health services, developing continuous training on "Human Health" for health professionals in general and primary-care nurses specifically, which may explain the success of its policy $[45,46]$.

The present study showed that there was no relationship between mortality rates due to CSPCs in the investigated population of the municipalities and FHS coverage, although this coverage increased by an average of $6 \%$ per year during the study period. A priori, the data are surprising and lead us to question the effectiveness of the FHS. However, there is a body of evidence that proves the effectiveness of the FHS [14, 15, 20, 47]. Therefore, it is necessary to consider that numerous factors in this evaluation contributed to the fact that men remain invisible in and through health services, ranging from individual vulnerabilities to social and programmatic vulnerabilities.

On the other hand, relationships were found between FHS coverage and mortality rates due to CSPCs in the groups of diseases preventable by immunization and sensitive conditions; infectious gastroenteritis and complications; nutritional deficiencies; ear, nose, and throat infections; asthma; angina; epilepsy; kidney and urinary tract infections; infections of the skin and subcutaneous tissue; and gastrointestinal ulcers. Discussions of this topic should include that access to the health system can be an important barrier for men in the care of their chronic conditions, whereas they can be assisted when the malady is acute $[13,17,18,20,21]$. A study considered a reference correlated the increase in FHS coverage with the tendency to reduce mortality rates from preventable causes of people under 75 years of age in both sexes. According to the authors, it is essential to expand the provision of primary health care, coupled with strong local governance to impact mortality rates, to obtain improvements in health outcomes in terms of reducing avoidable mortality rates [48].

The discontinuity of policies and structural changes in already consolidated programmes needs to be mentioned, since in Brazil, from 2016 to the present, a period of great political and economic fragility has been arisen from changes in labour rules and threats to the SUS [49, 50]. The Prevent Brazil Programme, established in November 2019 by the Ministry of Health, which establishes a new funding model for primary health care, highlights some of these losses. The establishment of this funding model threatens the FHS because it starts to consider registered people instead of registered teams, in addition to not favouring the implementation of actions specific to a given territory or population [51, 52]. It is believed that the evolution of the legislation of the SUS and its funding, the institution of new forms of team models for primary care, and the impacts of the current pandemic can discourage the

Page 9/14 
inclusion of the attributes of the FHS, compromising health care and thus, causing health indicators to rise [49, 50, 51]. It seems appropriate that society as a whole be positioned to protect the current Brazilian health system and that there be advances in studies that evaluate the impact of PHC on the health levels of the population.

An important limitation of this study is the existence of underreporting of deaths and incorrect inputs into the mortality information system, which can interfere with the reliability of the data produced. A strength of the study is the fact that it evaluates deaths due to CSPCs in men aged 20 to 59 years, a vulnerable group on which there is too little research, but which is the targe of the most recent government policy of the SUS, which still lacks consistent evaluations.

\section{Conclusion}

The mortality rates due to CSPCs in the male population aged 20 to 59 years in the municipalities of Goiás are not related to the implementation of PNAISH, given that all municipalities in Goiás have the policy implemented. Despite the growing trend of FHS coverage, overall mortality rates due to CSPCs in the male population aged 20 to 59 years are not related to coverage. When the mortality rates are stratified by CSPC group, there was a relationship between FHS coverage and deaths from diseases preventable by immunization; sensitive conditions; infectious gastroenteritis and complications; nutritional deficiencies; ear, nose, and throat infections; asthma; angina; epilepsy; kidney and urinary tract infections; infections of the skin and subcutaneous tissue; and gastrointestinal ulcers.

The spatial analysis showed variation in the pattern of deaths due to CSPCs in the study population. It is urgent that we homogenize FHS coverage, as well as take intersectoral actions for health promotion related to human health in all municipalities.

The analyses of temporal trends of deaths due to CSPCs in the general population of this study indicate the stability of these rates in the investigated period. However, when stratifying the mortality rates by CSPC group, we found an increase in the rates of bacterial pneumonia, asthma, SAH, epilepsy, kidney and urinary tract infection, and skin and subcutaneous tissue infection.

These findings reinforce the ineffectiveness of the preparation and execution of PNAISH and warrants the implementation of evaluation and replanning measures as early as possible and the integration of men's health policies with other public policies by managers and health professionals.

\section{Abbreviations}

National Policy for Integral Attention to Male Health (PNAISH)

Unified Health System (Sistema Único de Saúde - SUS)

Primary health care $(\mathrm{PHC})$

Family Health Strategy (FHS)

Conditions sensitive to primary care (CSPCs)

Diabetes mellitus (DM)

Systemic arterial hypertension (SAH)

Heart failure (HF)

\section{Declarations}

\section{Ethics approval and consent to participate}

Not applicable

\section{Consent for publication}

Not applicable

\section{Availability of data and materials}

https://drive.google.com/file/d/1uGXalh2NePSgYhY4Wy1BS2rzxhANkOVq/view?usp=sharing

\section{Competing interests}

The authors declare that they have no competing interests

\section{Funding}


This study did not receive funding from any funding agency in the public, commercial or non-profit sectors.

\section{Authors' contributions}

All authors read and approved the final manuscript

\section{Acknowledgements}

Not applicable

\section{References}

1. WHO. World health statistics 2019: monitoring health for the SDGs, sustainable development goals. Geneva: World Health Organization; 2019.

2. De Oliveira J, Corrêa Á, Silva L, Mozer Rosa I, Marien Knupp R. Perfil epidemiológico da mortalidade masculina: contribuições para enfermagem. Cogitare Enferm. (22)2: e49724, 2017.

3. Coelho EBS, Eduardo S, Bolsoni CC, Conceição TB. Política nacional de atenção integral a saúde do homem. 2018. http://www.saude.gov.br/images/pdf/2018/novembro/07/livroPol-ticas-2018.pdf Accessed 08 Sep 2020.

4. Ministério da Saúde. Portaria n 1.944, de 27 de Agosto de 2009.Institui no âmbito do Sistema Único de Saúde (SUS), a Política Nacional de Atenção Integral à Saúde do Homem. 2009. https://bvsms.saude.gov.br/bvs/saudelegis/gm/2009/prt1944_27_08_2009.html Accessed 27 Aug 2009.

5. Griffith DM. Biopsychosocial approaches to men's health disparities research and policy. Behav Med. 2016;42:211-5.

6. Teo $\mathrm{CH}, \mathrm{Ng}$ CJ, Ho CC, Tan HM. A consensus on men's health status and policy in Asia: a Delphi survey. Public Health. 2015;129:60-7.

7. Richardson N, Smith JA. National men's health policies in Ireland and Australia: what are the challenges associated with transitioning from development to implementation? Public Health. 2011;125:424-32.

8. Esmailzade H, Mafimoradi S, Mirbahaeddin E, Rostamigooran N, Farzadfar F. Devising a national men's health policy document: the current challenges to men's health in Iran. Int J Men's Health. 2016;15:174-93.

9. Baker P. Men's health: time for a new approach. Phys Ther Rev. 2018;23:144-50.

10. Baker P. A European men's health strategy: here at last. Trends Urol Men's Health. 2019;10:21-4.

11. Goiás. Lei n 19.034, de 07 de outubro de. Dispõe sobre a implantação da política estadual de atenção integral à saúde do homem no âmbito do estado de Goiás. 2015. https://diariooficial.abc.go.gov.br/portal/visualizacoes/pdf/571/\#/p:1/e:571 Accessed 20 Jul 2021.

12. Gomes R, Leal AF, Knauth DR, Silva GSND. Sentidos atribuídos à política voltada para a Saúde do Homem. Ciencia \& Saude Coletiva. 2012;17:2589-96.

13. Alves A, Coura A, França I, Magalhães I, Rocha M, Araújo R. Acesso de primeiro contato na atenção primária: uma avaliação pela população masculina. Rev Bras Epidemiol. 2020;23:e200072.

14. Macinko J, Mendonça C. Estratégia saúde da família, um forte modelo de atenção primária à saúde que traz resultados. Saúde em Debate. 2018;42:18-37.

15. OPAS. Organização pan-Americana da saúde atenção primária à saúde. 2020. https://www.paho.org/pt/topicos/atencao-primária-saude. Accessed 18 Out 2020.

16. Alfradique M, Bonolo P, Dourado I, Lima-Costa M, Macinko J, Mendonça $\mathrm{C}$, et al. Internações por condições sensíveis à atenção primária: a construção da lista Brasileira como ferramenta para medir o desempenho do sistema de saúde (Projeto ICSAP - Brasil). Cad Saúde Pública. 2009;25:1337-49.

17. González-Vélez AE, Mejía CCC, Padilla EL, Marín SYM, Bobadilla PAR, Sánchez JPR, et al. Ambulatory care sensitive conditions hospitalization for emergencies rates in Colombia. Rev Saude Publica. 2019;53:36.

18. Sarmento J, Rocha JVM, Santana R. Defining ambulatory care sensitive conditions for adults in Portugal. BMC Health Serv Res. 2020;20:754.

19. Ministério da Saúde. Portaria n. 221/SAS de 17 de abril de 2008, que define a lista Brasileira de internações por condições sensíveis à atenção primária. Diário Oficial da União da República Federativa do Brasil. 2008.

https://bvsms.saude.gov.br/bvs/saudelegis/sas/2008/prt0221_17_04_2008.html Accessed 18 Abr 2008.

20. Pinto LF, Giovanella L. Do programa à estratégia saúde da família: expansão do acesso e redução das internações por condições sensíveis à atenção básica (ICSAB). Ciência \& Saúde Coletiva. 2018;23:1903-14.

21. Cesaro BC, Dos Santos HB, da Silva FNM. Masculinities inherent to the Brazilian men's health policy la masculinidad inherente a la política sobre la salud del hombre en Brasil. Rev Panam Salud Publica. 2018;42:e119.

22. IBGE - Instituto Brasileiro de Geografia e Estatística. Diretoria de pesquisas, coordenação de população e indicadores sociais, estimativas da população. 2020. https://cidades.ibge.gov.br/brasil/go/panorama Accessed 10 Jul 2020.

23. IMB. Instituto mauro borges de estatísticas e estudos socioeconômicos. 2021. https://www.imb.go.gov.br/files/docs/públicacoes/goias-emdados/godados2017.pdf Accessed 03 Jul 2021.

24. Ministério da Saúde (BR), DATASUS. Departamento de Informática do Sistema Único de Saúde. 2020. https://datasus.saude.gov.br/transferencia-dearquivos/ Accessed 17 Jun 2020.

25. Ministério da Saúde (BR), DATASUS. Departamento de Informática do Sistema Único de Saúde. Informações de Saúde (TABNET). Demográficas e Socioeconômicas. 2020. http://tabnet.datasus.gov.br/cgi/deftohtm.exe?popsvs/cnv/popbr.def Accessed 22 june 2020. 
26. Ministério da Saúde (BR). Sistema de apoio ao relatório de gestão - SARGSUS. 2020c.

https://sargsus.saude.gov.br/sargsus/login\%21 carregaRelatorioExterno.action?codUf=52\&codTpRel=01\&SARGSUS_TOKEN=DERU-5626-KBZX-8CZY11XO-9VTN-E46C-9NFL Accessed 22 june 2020.

27. GOIÁS, Secretaria de estado da saúde de Goiás (BR). Boletim da Saúde do Homem. 2019. https://www.saude.go.gov.br/files/boletins/informativos/saude-homem/BOLETIMABRIL2019.pdf Accessed 08 Sep 2020.

28. Ministério da Saúde (BR), Secretaria de atenção primária à saúde (SAPS). e-Gestor Atenção Básica 2020. https://egestorab.saude.gov.br/paginas/acessoPublico/relatorios/relHistoricoCoberturaAB.xhtml Accessed 28 Nov 2020.

29. Kochanek KD, Murphy SL, Xu J, Arias E. Deaths: Final Data for 2017. Natl Vital Stat Rep. 2019;68:1-77.

30. Griffith DM, Semlow AR, Leventhal M, Sullivan C. The tennessee men's health report card: a model for men's health policy advocacy and education. Am J Mens Health. 2019;13:1557988319882586.

31. CONASS - Conselho Nacional dos Secretários de Saude. Painel de análise do excesso de mortalidade por causas naturais no Brasil em 2020.2020. https://www.conass.org.br/indicadores-de-obitos-por-causas-naturais/ Accessed 16 Out 2020.

32. Andrade MV, Coelho AQ, Neto MX, Carvalho LR, Atun R, Castro MC. Correction: transition to universal primary health care coverage in Brazil: Analysis of uptake and expansion patterns of Brazil's family health strategy (1998-2012). PLoS One. 2021;16:e0251764.

33. Pereira JQ, Klein C, Meyer DEE. PNAISH: uma análise de sua dimensão educativa na perspectiva de gênero. Saúde e Sociedade. 2019;28:132-46.

34. Sousa N, Rehem T, Santos W, Santos C. Internações sensíveis à atenção primária à saúde em hospital regional do distrito federal. Revista Brasileira de Enfermagem. 2016;69:118-25.

35. Ministério da Saúde (BR). Plano de ações estratégicas para o enfrentamento das doenças crônicas não transmissíveis (DCNT) no Brasil $2011-2022$. 2011. https://bvsms.saude.gov.br/bvs/publicacoes/plano_acoes_enfrent_dcnt_2011.pdf Accessed 16 Out 2020.

36. Ministério da Saúde, Portaria nº 1.317 ddnd. Aprova o protocolo clínico e diretrizes terapêuticas da asma. Brasília (DF). 2013. https://bvsms.saude.gov.br/bvs/saudelegis/sas/2013/prt1317_25_11_2013.html Accessed 02 Jul 2021.

37. Cetolin SF, Bohrz S, Moser AMM, Favero PH, Cetolin VB, Marmitt LP. Population aging and hospitalization for sensitive causes to primary care. Int J Adv Eng Res Sci. 2021;8:1.

38. Oliveira JEP, Vencio S. Diretrizes da sociedade Brasileira de diabetes, 2013-2014. 2014. http://www.sgc.goias.gov.br/upload/arquivos/201405/diretrizessbd-2014.pdf Accessed 04 Jul. 2021.

39. Ministério da Saúde, Secretaria de Atenção à Saúde, Departamento de Atenção Básica. Estratégias para o cuidado da pessoa com doença crônica: hipertensão arterial sistêmica. Brasília: Ministério da Saúde. 2014.

https://bvsms.saude.gov.br/bvs/publicacoes/hipertensao_arterial_sistemica_cab37.pdf Accessed 04 Jul. 2021.

40. Australian Government, Australian Institute of Health and Welfare. How many Australians have diabetes? 2018. https://www.aihw.gov.au/reports/diabetes/diabetes/contents/how-many-australians-have-diabetes Accessed 04 Jul, 2020.

41. Domingues CMAS, Maranhão AGK, Teixeira AMdS, Fantinato FFST, Domingues RAS. 46 anos do Programa Nacional de Imunizações: uma história repleta de conquistas e desafios a serem superados. Cadernos de Saude Publica. 2020;36:e00222919.

42. Paiva Neto F, Sandreschi P, Dias MS, Loch M. Dificultades del autocuidado masculino: discursos de hombres participantes en un grupo de educación para la salud. Salud Colectiva. 2020;16:e2250.

43. Müller RF, Birman J. Negotiating knowledge and power: the national policy for comprehensive men's healthcare and the Brazilian society of urology. Hist Cienc Saude Manguinhos. 2016;23:703-17.

44. Griffith DM, Metzl JM, Gunter K. Considering intersections of race and gender in interventions that address US men's health disparities. Public Health. 2011;125:417-23.

45. Rizio TA, Thomas WJ, O'Brien AP, Collins V, Holden CA. Engaging primary healthcare nurses in men's health education: A pilot study. Nurse Educ Pract. 2016;17:128-33.

46. Osborne A, Carroll P, Richardson N, Doheny M, Brennan L, Lambe B. From training to practice: the impact of ENGAGE, Ireland's national men's health training programme. Health Promot Int. 2018;33:458-67.

47. Morosini MVGC, Fonseca AF, Lima LD. Política nacional de atenção básica 2017: retrocessos e riscos para o Sistema Único de Saúde. Saúde em Debate. 2018;42:11-24.

48. Hone T, Rasella D, Barreto M, Atun R, Majeed A, Millett C. Large reductions in amenable mortality associated with brazil's primary care expansion and strong health governance. Health Aff (Millwood). 2017;36:149-58.

49. Santos I, Sulpino Vieira F. The Right to healthcare and fiscal austerity: the Brazilian case from an international perspective. Ciencia \& Saude Coletiva. 2018;23:2303-14.

50. Machado CV, Silva GAE. Lutas políticas por um sistema universal de saúde no Brasil: sucessos e limites na redução das desigualdades. Saúde Global. 2019;15:77.

51. Melo EA, Almeida PF, Lima LD, Giovanella L. Reflexões sobre as mudanças no modelo de financiamento federal da atenção básica à Saúde no Brasil. Saúde em Debate. 2020;43:137-44.

52. Ministério da Saúde, Portaria No 2.979 ddnd. Institui o programa previne Brasil, que estabelece novo modelo de financiamento de custeio da atenção primária à saúde no âmbito do sistema único de saúde, por meio da alteração da portaria de consolidação n 6/GM/MS, de 28 de Setembro de 2017 . 2019. https://www.in.gov.br/en/web/dou/-/portaria-n-2.979-de-12-de-novembro-de-2019-227652180 Accessed 27 Out 2020.

Page $12 / 14$ 


\section{Figures}

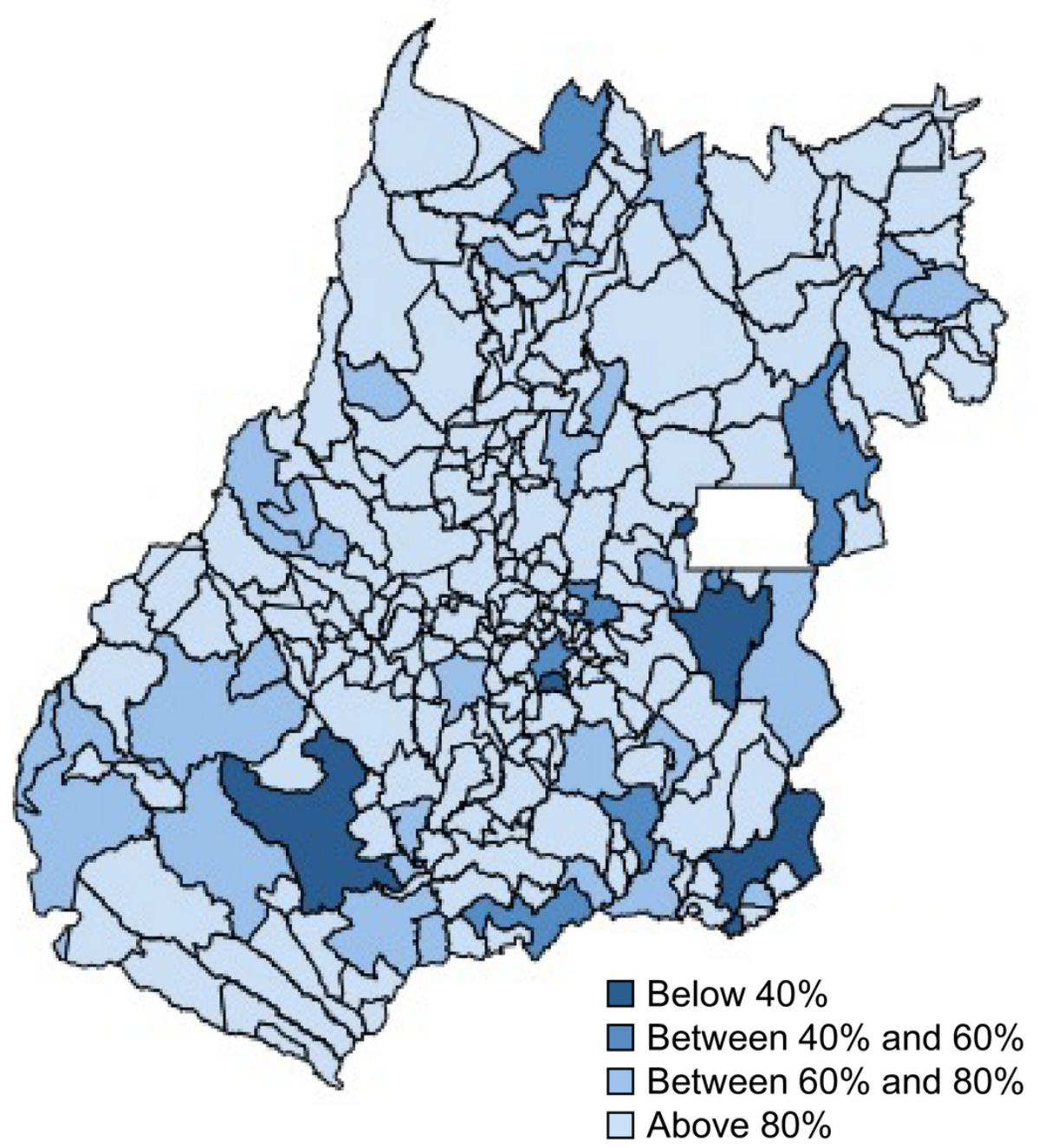

Figure 1

Spatial distribution of the average coverage of the FHS, 2009-2018. Goiás, Brazil, 2021.

Source: e-Gestor - Primary Care, 2020. 


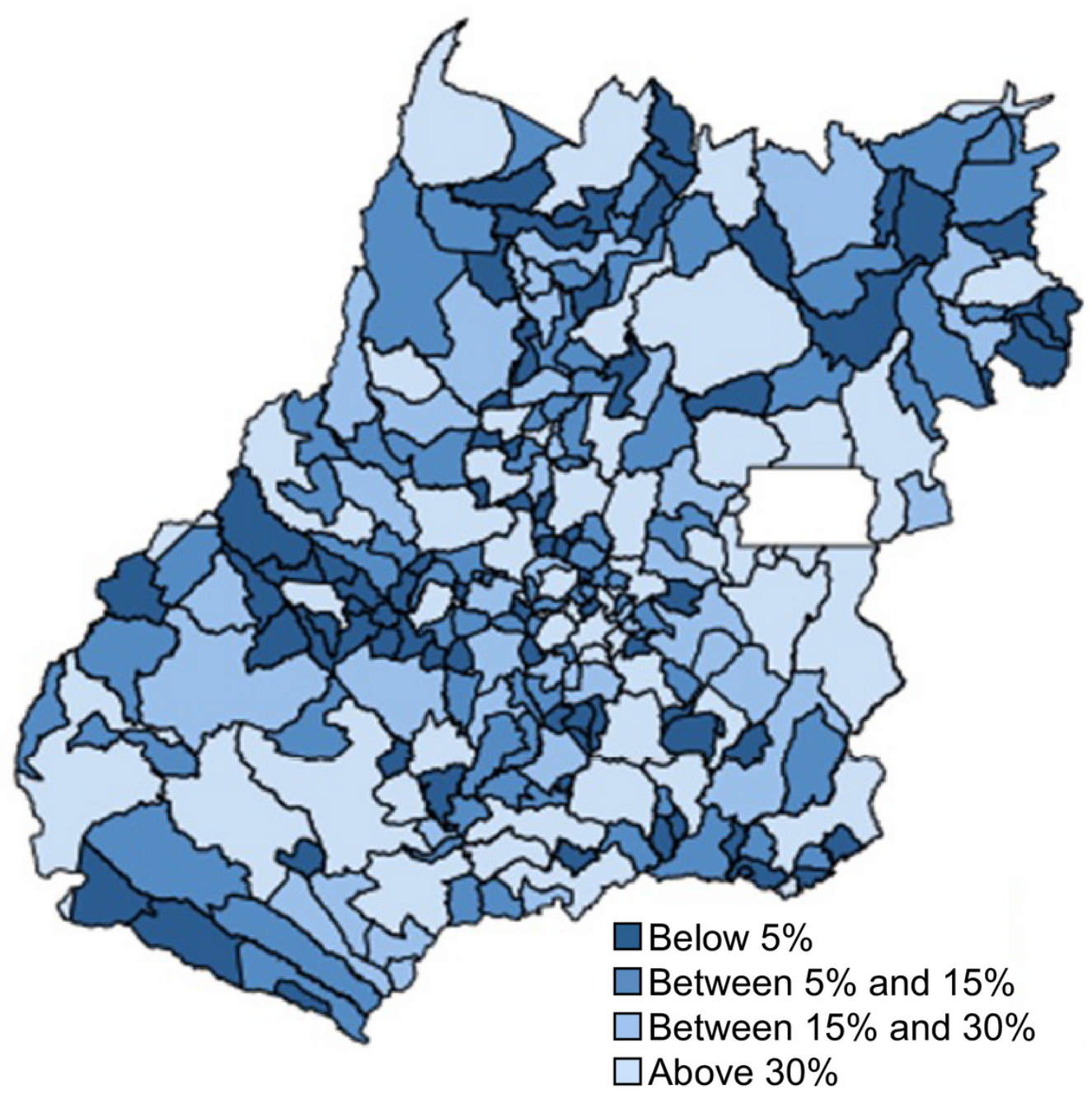

Figure 2

Spatial distribution of male deaths by CSPC group, aged 20-59 years, 2009-2018. Goiás, Brazil, 2021.

Source: DATASUS, Ministry of Health, 2020. 